Nataša Kljajić ${ }^{1}$

Drago Cvijanović ${ }^{2}$

Slavica Arsić ${ }^{3}$

Institute of Agricultural Economics, Belgrade
SCIENTIFIC REVIEW ARTICLE doi:10.5937/ekonomika1504057K Received: October 16, 2015 Accepted: November 12, 2015

\title{
POTENTIALS AND ANALYSIS OF THE PRIMARY CROP CULTIVATION IN THE MUNICIPALITY PECINCI ${ }^{4}$
}

\begin{abstract}
Territory of the municipality Pecinci area is characterized by intensive agricultural production within which the most developed are crop and vegetable production. Favourable climatic characteristics, configuration of terrain, as well as soil structure are favourable to development of these sectors of agriculture. Accordingly, in the paper were presented characteristics and peculiarities of this municipality area, as well as the crop cultivation potentials, according to data of statistical yearbooks of the Republic of Serbia Statistical Office. There was also analyzed production and trends of industrial and vegetable plants, as well as fruits and grapes through basic indexes for the ten-years-lasting period (2003-2013). In accordance to available data, we have concluded that the municipality Pecinci has significant production capacities, on which is possible to develop a modern agricultural production which can satisfy consumers' needs, it preserves natural resources and provides development of rural areas.
\end{abstract}

Key words: Pecinci, agriculture, crop cultivation.

JEL: Q10, Q19, R00

\section{ПОТЕНЦИЈАЛИ И АНАЛИЗА ПРИМАРНЕ БИЉНЕ ПРОИЗВОДЊЕ У ОПШТИНИ ПЕЪИНЦИ}

\section{Абстракт}

Територија подручја општине Пећинци се одликује интензивном пољопривредном производњом у оквиру које је највише развијено ратарство и повртарство. Развијаюу ових пољопривредних грана погодују повољне климатске карактеристике, конфигураџија терена, као и састав земљишта. Сходно томе, у раду су, на основу података Статистичких годишњака Републичког завода за статистику и података из неких од докумената локалних истраживања, приказане карактеристике и специффичности

\footnotetext{
1 natasa_k@iep.bg.ac.rs

2 drago_c@iep.bg.ac.rs

3 slavica_a@iep.bg.ac.rs

${ }^{4}$ Acknowledgements - This paper is part of research on the project No 46006: "Sustainable agriculture and rural development in the function of achieving the strategic goals of the Republic of Serbia in the Danube region", financed by the Ministry of Education, Science and Technological Development of the Republic of Serbia.
} 
подручја ове општине као и потенцијали биљне производње. Анализирана је производюа и кретање производње индустријског и повртарског биља, као и воћа и грожђа кроз базне индексе за десетогодишњи период (20032013. година). На основу расположивих података дошло се до закључка да ова општина поседује значајне производне капацитета на којима је могуће развијати савремену пољопривредну производюу која задовољава потребе потрошача, чува природне ресурсе и омогућава развој руралних средина.

Кључне речи: Пећинци, пољопривреда, биљна производња.

\section{Introduction}

The municipality Pecinci, as one of the smaller municipalities in Autonomous Province of Vojvodina, with numerous heavily populated settlements, belongs to Srem District. It lies actually in the sub-region of Srem, in the part of a wider geographic region Podluzje. Although it lies on the territory of AP Vojvodina, this municipality belongs to the Belgrade Metropolitan Area (functional urban area), together with Stara Pazova, Opovo, Pancevo, Indjija and Ruma (http://www.pecinci.org/opstina_pecinci/o_nama.1.html).

The area of the territory Pecinci amounts $488.65 \mathrm{~km}^{2}$ (average for APV $=479.52$ $\mathrm{km}^{2}$ ) and by its size, it is in the eighteenth place in AP Vojvodina. The municipality Pecinci has 19,679 inhabitants (Municipal Yearbook, 2014).

A centre of the municipality is the settlement Pecinci, which lies in the north part of this municipality. Eccentric position of the central settlement, as well as the vicinity of developed city centres, especially Belgrade, affects the orientation (in many functions) of individual settlements of this municipality toward these centres.

Populated settlements in the municipality Pecinci are: Asanja, Brestac, Dec, Donji Tovarnik, Karlovcic, Kupinovo, Obrez, Ogar, Pecinci, Popinci, Prhovo, Sibac, Sremski Mihaljevci, Subotiste and Simanovci.

In the vicinity of Pecinci lies Obedska bara (Obedska Marsh), the protected reserve of fauna, very attractive with surrounding forests in which are hunting-grounds and vacation areas. It is, in international sense, a significant plant area, as well as international significant area for birds.

Advantageous climatic characteristics, configuration of the terrain, as well as favourable soil structure (chernozem and brown forest soil) are favourable for agricultural production.

Production and trends of production of industrial and vegetable crops, also and fruits and grapes is seen through the indices for the ten-year period (2003-2013).

\section{Results and discussions}

The results are shown by crops after which they give directions for the future development of agriculture in this municipality.

\section{Crop cultivation}

Looking from the viewpoint of economy, land is a necessary condition for agricultural production and the most important element of all agricultural activities. As 
a natural gift it has no value. However, from the moment of its use in the process of production, it becomes the product of human activity, which could be sold and bought at a certain price, functioning as a potential for the production of goods and services. From that reason, almost all countries initiate and apply in practice concrete measures regarding the way of land use, improvement of its production capability, property protection and ecosystem protection (Kljaji, et al., 2011.).

Total utilized agricultural land in the Republic of Serbia in the year 2013 was 5.069.000 ha, according to data of the Statistical Yearbook of RS for the year 2014. Of which 3.298 .000 ha $(65 \%)$ was under plough land and gardens, 239.000 ha $(5 \%)$ was under orchards, 50.000 ha (1\%) under vineyards, 653.000 ha $(13 \%)$ under meadows and 829.000 ha $(16 \%)$ under pastures.

The region of Vojvodina, where the municipality Pecinci belongs to, according to the same source, has 1.745.000 ha of land used in agriculture. Of which 1.579.00 ha $(90 \%)$ are plough land and gardens, 19.000 ha $(1,2 \%)$ are orchards, 8.000 ha $(0.8 \%)$ are vineyards, 39.000 ha $(2,2 \%)$ are meadows and 101.000 ha $(5,8 \%)$ are pastures.

The municipality Pecinci is typically rural municipality, with low to medium population density (a hundred inhabitants per a $\mathrm{km}$ ) and a high percentage of active rural population.

The north and mid part of the municipality Pecinci is under agricultural land, while the south part cover, beside the agricultural land, also large complex of forests and forest land within the SNR "Obedska bara" in the protected zone.

In the table 1 was shown an utilized agricultural area on the area of this municipality for the period 2000-2013, through plough land and gardens where dominance can be seen, and then in the form of orchards, vineyards, meadows and pastures.

Table 1. Structure of using agricultural land on the area of the municipality Pecinci for the period 2000-2013

\begin{tabular}{|c|c|c|c|c|c|c|c|c|c|c|c|}
\hline \multirow{3}{*}{ Year } & \multirow{3}{*}{$\begin{array}{l}\text { Agricultural } \\
\text { area }\end{array}$} & \multicolumn{5}{|c|}{ Arable land and gardens } & \multirow{3}{*}{ orchards } & \multirow{3}{*}{ vineyards } & \multirow{3}{*}{ meadows } & \multirow{3}{*}{ grasslands } & \multirow{3}{*}{$\begin{array}{l}\text { Ponds, } \\
\text { reeds }\end{array}$} \\
\hline & & \multirow{2}{*}{ total } & \multicolumn{4}{|c|}{ thereof } & & & & & \\
\hline & & & wheat & $\begin{array}{c}\text { Industrial } \\
\text { plants }\end{array}$ & $\begin{array}{c}\text { Gardening } \\
\text { plants }\end{array}$ & roughage & & & & & \\
\hline 2000 & 34408 & 31423 & 21578 & 3850 & 3272 & 3367 & 241 & 21 & 780 & 1052 & 891 \\
\hline 2001 & 34129 & 31128 & 20711 & 4053 & 3062 & 2245 & 255 & 24 & 793 & 1044 & 888 \\
\hline 2002 & 34129 & 31128 & 20711 & 4053 & 3062 & 2245 & 255 & 21 & 793 & 1044 & 888 \\
\hline 2003 & 34591 & 31528 & 20344 & 4911 & 2948 & 2176 & 217 & 20 & 846 & 1093 & 887 \\
\hline 2004 & 31690 & 31604 & 21370 & 3693 & 3427 & 1865 & 218 & 20 & 854 & 1106 & 888 \\
\hline 2005 & 34690 & 31667 & 21241 & 3318 & 3373 & 1739 & 210 & 20 & 799 & 1106 & 888 \\
\hline 2006 & 34599 & 31512 & 20451 & 2965 & 3727 & 1995 & 211 & 20 & 849 & 1116 & 891 \\
\hline 2007 & 33833 & 31492 & 21607 & 3061 & 3952 & 2216 & 229 & 20 & 978 & 1114 & - \\
\hline 2008 & 34710 & 31786 & 22201 & 3491 & 3674 & 2101 & 214 & 20 & 811 & 1002 & - \\
\hline 2009 & 34710 & 31571 & 22381 & 3190 & 3497 & 2279 & 214 & 20 & 936 & 1092 & - \\
\hline 2010 & 34710 & 31533 & 22829 & 3072 & 3378 & 2159 & 209 & 20 & 959 & 1112 & - \\
\hline 2011 & 34705 & 31537 & 22531 & 3697 & 3173 & 2053 & 209 & 20 & 960 & 1112 & - \\
\hline 2012 & 26249 & 24938 & & & 3332 & & 211 & 6 & & 094 & - \\
\hline 2013 & 26249 & 24938 & & & 3332 & & 211 & 6 & & 094 & - \\
\hline
\end{tabular}

Source: author's calculation based on data from the Statistical Yearbook of the Republic of Serbia for the corresponding year 
If we analyze the year 2013, as the last year in the table 1, we can conclude that in the structure of arable land, agricultural land, the highest share have plough land and gardens (grain, industrial crops, forage crops and vegetables) with $95 \%$. Orchards with $0,8 \%$ and vineyards with $0,02 \%$ cover negligible areas of this municipality, while meadows and pastures participate with $4,2 \%$ in the structure of agricultural land, occupying larger areas in regard to fruits and grapevine. The rest $0,78 \%$ are fish ponds, reeds and marshes.

Table 2. Production of industrial plants on the area of the municipality Pecinci

\begin{tabular}{|c|c|c|c|c|c|c|}
\hline Year & Wheat & $\begin{array}{c}\text { Compared } \\
\text { to the base } \\
\text { year 2003 } \\
(\mathrm{t})\end{array}$ & Corn & $\begin{array}{c}\text { Compared to } \\
\text { the base year } \\
2003\end{array}$ & Sugar beet & $\begin{array}{c}\text { Compared to the } \\
\text { base year 2003 }\end{array}$ \\
\hline 2003 & 14.836 & 100 & 38.988 & 100 & 39.999 & 100 \\
\hline 2004 & 31.814 & 114,4 & 70.548 & 80,9 & 30.790 & 77,0 \\
\hline 2005 & 17.187 & 15,8 & 85.022 & 118,1 & 24.039 & 60,0 \\
\hline 2006 & 15.631 & 5,3 & 63.723 & 63,4 & 21.262 & 53,2 \\
\hline 2007 & 20.429 & 37,7 & $42 . .480$ & 9,0 & 17.872 & 44,7 \\
\hline 2008 & 20.174 & 36,0 & 58.676 & 5,04 & 14.020 & 35,1 \\
\hline 2009 & 17.277 & 16,4 & 75.352 & 93,2 & 24.269 & 60,7 \\
\hline 2010 & 14.443 & 97,4 & 74.602 & 91,3 & 95.43 & 23,9 \\
\hline 2011 & 19.797 & 33,4 & 63.042 & 61,7 & 117.25 & 29,3 \\
\hline 2012 & 19.096 & 28,7 & 22.406 & $-42,5$ & 7.134 & 17,8 \\
\hline 2013 & 30.433 & 105,1 & 60.319 & 54,7 & 7.800 & 19,5 \\
\hline Everage & 20101,5 & - & 59559,8 & - & 18950,3 & - \\
\hline
\end{tabular}

Source: author's calculation based on data from the Statistical Yearbook of the Republic of Serbia for the corresponding year

According to the presented table 2, the production of industrial plants on the areas of Pecinci municipality, where has been shown trends of wheat, maize and sugar beet production for the period 2003-2013, we can notice that there was increase of wheat and maize production, while regarding sugar beet had decreased in the observed ten-yearslasting period. By calculation of a basic index in regard to the year 2013, for all three mentioned crops, we have concluded the following:

The production of wheat in 2014 had the highest increase of production of $114,4 \%$ and in the last year, 2013, of 105,1\%. Chronologically observed, according to the basic indexes, production has ranged cyclically, in positive sense, because in some years production has increased more, and in some years less. For example, in the year 2007, production was increased for $37,7 \%$, in 2008 for $36,0 \%$, in 2011 for $33,4 \%$ and in 2012 for $28,7 \%$. However, there are years with minimum increase, like in $2005(15,8 \%)$ and $2009(16,4 \%)$. Only in 2010, according to calculation, production was for $2,6 \%$ lower in regard to the basic year 2003.

Regarding maize, the highest increase was in 2005 (118,1\%), then followed 2009 with increase of 93,2\%. The approximate increase was in $2010(91,3 \%)$, in 2004 a production index was amounted 80,9\%, in 2006 for $63,4 \%$, in 2011 for $61,7 \%$ and in 2013 is $54,7 \%$ in regard to the basic year. However, there were years with lower percentage increase of production, as: the year 2007 with $9,0 \%$ and 2008 with only $5,04 \%$ of increase in regard to the basic year 2003. Only in 2012 was noticed decrease of maize production in regard to the basic year, for $42,5 \%$. 
Calculating the index in regard to the basic year, we can notice a constant decrease of production regarding sugar beet, especially in 2012 (for 82,2\%) and in 2013 (for 80,5\%). In 2010 and 2011 decrease of index had ranged from 76,1\% to 70,7\%. Slightly lower production of sugar beet was in 2008 for $64,9 \%$, in 2007 for $55,3 \%$, in 2006 for $46,8 \%$, in 2005 for $40,0 \%$. The smallest decrease of production percentage was in 2004 and it was amounted $23,0 \%$.

For successful business activity in the field of vegetable growing, it is necessary to develop and organize a modern agricultural production, both outdoor and in protected space (green houses and cloches), along with application of modern mechanization, irrigation systems, fertilization and protection of soil and plants. It is inevitable, also, to provide equipment and to build objects for vegetable storage and placement improvement (Subić, Cecić, Vuković, 2008).

Table 3. Production of vegetables on the territory of the municipality Pecinci

\begin{tabular}{|c|c|c|c|c|c|c|}
\hline Year & $\begin{array}{c}\text { Sunflower } \\
(\mathrm{t})\end{array}$ & $\begin{array}{c}\text { Compared } \\
\text { to the base } \\
\text { year 2003 } \\
(\%)\end{array}$ & $\begin{array}{c}\text { Beans } \\
(\mathrm{t})\end{array}$ & $\begin{array}{c}\text { Compared to } \\
\text { the base year } \\
2003 \\
(\%)\end{array}$ & $\begin{array}{c}\text { Potato } \\
(\mathrm{t})\end{array}$ & $\begin{array}{c}\text { Compared to } \\
\text { the base year } \\
2003 \\
(\%)\end{array}$ \\
\hline 2003 & 4.170 & 100 & 266 & 100 & 2.406 & 100 \\
\hline 2004 & 3.911 & 93,8 & 581 & 118,4 & 5.314 & 120,9 \\
\hline 2005 & 3.067 & 73,5 & 460 & 72,9 & 5.663 & 135,4 \\
\hline 2006 & 3.096 & 74,2 & 574 & 115,8 & 6.589 & 173,9 \\
\hline 2007 & 2.705 & 64,9 & 398 & 49,6 & 6.874 & 185,7 \\
\hline 2008 & 3.716 & 89,1 & 277 & 4,1 & 5.278 & 119,3 \\
\hline 2009 & 4.328 & 3,8 & 405 & 52,3 & 5.220 & 117,0 \\
\hline 2010 & 3.726 & 89,3 & 341 & 28,2 & 4.451 & 85,0 \\
\hline 2011 & 4.884 & 17,1 & 399 & 50,0 & 6.134 & 154,9 \\
\hline 2012 & 3.662 & 87,8 & 245 & 92,1 & 3.251 & 35,1 \\
\hline 2013 & 5.505 & 32,0 & 420 & 57,9 & 4.573 & 90,1 \\
\hline Everage & 3888,2 & - & 396,9 & - & 5068,5 & - \\
\hline
\end{tabular}

Source: author's calculation based on data from the Statistical Yearbook of the Republic of Serbia for the corresponding year

As for vegetable production on the area of this municipality, for example was taken production of sunflower, bean and potato, for the observed period 2003-2013. According to calculation of the basic index, there was decrease of production in almost every year regarding sunflower production. The most significant decrease of production was in 2007 for $35,1 \%$, in 2008 for $10,9 \%$, in 2010 for $10,7 \%$ and in 2012 for $12,2 \%$. As opposed to it, the biggest increase was in the year $2013(32,0 \%)$, in $2011(17,1 \%)$ and in $2009(3,8 \%)$.

Regarding beans, the most significant increase of production was in 2004, 118,4\%, then in 2006 the production was increased for $115,8 \%$, in 2005 for $72,9 \%$ and in 2013 for $57,9 \%$ in regard to the basic year 2003. The smallest decrease of beans production was in $2012,7,9 \%$.

When it comes to potato production, by calculation of the basic index, there is a constant increase of production, so in 2007 it was increased for $185,7 \%$, in 2006 for $173,9 \%$, in 2005 for $135,4 \%$ and in 2011 for $154,9 \%$. The smallest increase of potato production was in 2012, for $35,1 \%$ in regard to the basic year 2003 .

To improve the growth of vegetable production in total and per capita, it is essential that the Ministry of Agriculture, institutes, agencies and other relevant institutions to 
collect and process data, their activities more focus on small farmers and allocate more funds (premium, subsidies and other incentives) and the picture of agricultural production will be better (Grujić, et al., 2014.).

Fruit production as plant production is characterized by a number of comparative advantages in relation to other branches of agriculture. In addition to employment opportunities for large numbers of workers, fruit can be attractive not only for farmers, but for the enterprising people of all other occupations. It allows the use of areas with different climatic conditions, local character and use of soil of less productive capacity, and land less productive and less favorable in terms of physical, chemical and other properties, and land on steeper slopes (Kljajić, \& Vuković, 2014.).

In the table 4 were presented trends in fruits and grape production on the area of the municipality Pecinci, where were also calculated the basic indexes in ten-year-lasting period.

Table 4. Production of fruits and grapes on the area of the municipality Pecinci

\begin{tabular}{|c|c|c|c|c|c|c|}
\hline Year & $\begin{array}{c}\text { Apples } \\
(\mathrm{t})\end{array}$ & $\begin{array}{c}\text { Compared to } \\
\text { the base year } \\
2003 \\
(\%)\end{array}$ & $\begin{array}{c}\text { Plums } \\
(\mathrm{t})\end{array}$ & $\begin{array}{c}\text { Compared to the } \\
\text { base year 2003 } \\
(\%)\end{array}$ & $\begin{array}{c}\text { Vine } \\
(\mathrm{t})\end{array}$ & $\begin{array}{c}\text { Compared to } \\
\text { the base year } \\
2003 \\
(\%)\end{array}$ \\
\hline 2003 & 424 & 100 & 737 & 100 & 39 & 100 \\
\hline 2004 & 350 & 82,5 & 702 & 95,2 & 66 & 69,2 \\
\hline 2005 & 458 & 8,0 & 646 & 87,7 & 52 & 33,3 \\
\hline 2006 & 558 & 31,6 & 872 & 18,3 & 66 & 69,2 \\
\hline 2007 & 631 & 48,8 & 814 & 10,4 & 60 & 53,8 \\
\hline 2008 & 531 & 25,2 & 736 & 99,8 & 120 & 207,7 \\
\hline 2009 & 696 & 64,2 & 1.060 & 43,8 & 66 & 69,2 \\
\hline 2010 & 292 & 68,9 & 330 & 44,8 & 41 & 5,1 \\
\hline 2011 & 505 & 19,1 & 875 & 18,7 & 39 & 100 \\
\hline 2012 & 226 & 53,3 & 432 & 58,6 & 39 & 100 \\
\hline 2013 & 790 & 86,3 & 1.244 & 68,8 & 122 & 212,8 \\
\hline Everage & 496,5 & - & 768,0 & - & 64,5 & - \\
\hline
\end{tabular}

Source: author's calculation based on data from the Statistical Yearbook of the Republic of Serbia for the corresponding year

Fruit production was represented with apple production, where according to the basic indexes we can say that the biggest increase of production was in the year 2013, for $86,3 \%$ and in 2009 for $64,2 \%$, which meant that the entire production of apples was increasing. However, there were three years when production was decreased, which was probably the consequence of weather conditions, which were unfavourable for these varieties of fruit. So in the year 2012 we had the biggest decrease of production in regard to the basic year 2003 (46,7\%). Decrease was also noticed in 2010 for 31,1\% and in 2004 when production was decreased for $17,5 \%$.

The presented basic indexes for plum production point out to increase of this production in the analyzed period. In the last observed year 2013 production was increased for $68,8 \%$ and in 2009 , it was increased for $43,8 \%$ in regard to the year 2003 , taken as the basic one.

The years 2010 and 2012 were the years in which was the most significant decrease of plum production; in accordance to the basic indexes, in the year 2010 (even for 55,2\%) and in the year 2012 with 41,4\% lower production. Here also belongs the year 2005 with small index of production decrease of $12,3 \%$, as well as 2004 with $4,8 \%$. 
Observing trends of grape production in this municipality, we can see that some years have approximately the same production as the years 2011 and 2012, according to the basic indexes, which in regard to other observed years with increase of grape production, represent decrease of production. The years with the biggest production of grape are: 2008 with $207,7 \%$ and 2013 with $213,8 \%$, although in all other years there were increase of production of $53,8 \%$ and over $69,2 \%$ in regard to the basic year 2003 . Only in 2010 was the smallest increase of production for $5,1 \%$.

Considering the presented results we can conclude that this area of the municipality Pecinci is considered to be the area favourable for development of industrial plants and vegetable production, as well as for fruits and grape production, taking also into consideration a high percentage of employable rural population.

\section{Directions of agriculture development in the next period}

This is what characterizes agriculture of the municipality Pecinci as follows:

- Soil of relatively high production ability which ensures growing all varieties of crops and vegetables;

- Favourable climatic and pedological conditions;

- Favourable preconditions for bee keeping;

- Opportunities for growing medicinal herbs and flowers;

- Vicinity of big cities' markets as very significant consumers of agricultural products,

- Underdevelopment of farm holdings (natural character of production, lower yields in regard to agricultural enterprises, poor technological equipment and obsolescence of means for production, fragmentized property and numerous elderly households),

- Bad performances of agricultural enterprises (poor technical equipment, obsolete mechanization, overabundant and inadequate structure of employees with regard to needs, unfavourable economic results, inefficient production), and

- Inadequate treatment and over-utilization of agricultural land.

The basic planning orientation for intensive use of agricultural land and for its protection implies primarily a rational farming of agricultural land and its protection, organization and use according to sustainability principles. Protection of top quality agricultural land as the natural resources and potential for agriculture development should be priority. It is also necessary to undertake some measures and activities to protect agricultural land on those terrains jeopardized by the erosion process and by raising and maintaining the agro-protective belts, by planting perennial woody plants, as well as by a permanent control of implementing these measures by the authorities.

The basis of crop production in this municipality area is primarily wheat and maize, which wouldn't be changed in the future for sure. The average and total yields point out seriously to a need for using irrigation and drainage on areas of most favourable soil for intensive agricultural production, according to the situation considering the water-air regulations of land in the production season (Cvijanović, et al.,, 2009.).

In regard to the extremely favourable natural conditions and the vicinity of big cities markets, especially Belgrade and Novi Sad, it is desirable to increase the production of crops in terms of growing early vegetables in plastic-foil houses and glasshouses. In regard to very convenient natural conditions and the vicinity of city markets, especially Belgrade 
and Novi Sad, it is preferable to increase the production of vegetable crops as cultivation of early vegetables in greenhouses and glasshouses. In that case, the production of vegetables can be economically profitable especially in protected, controlled terms of production (greenhouses, glasshouses), with obligatory use of irrigation, by which use can stabilize, i.e. increase food production and stimulate the development of all agricultural branches, as well as the others processing and economy branches (Kljajić, et al., 2009a.).

In this paper was not analyzed livestock production in the municipality Pecinci, while it was inevitable to establish the optimal ratio between plant and livestock production in the specific area, it is worth mentioning that livestock production as the traditional economic sector can strengthen significantly by activating the existing and raising new farms on adequate land in order to produce meat, milk and dairy products.

Fruit growing represents also a potential developmental line.

In the coming period, development of agriculture will get its significance through the related food industry:

a) Food industry with a higher level of finalization (e.g. production of frozen food etc.), and

b) Processing products via small family households (production and processing of meat, milk, fruits, vegetables, flour).

Accordingly, a special support has been given to the initiatives for construction of farm facilities for processing, drying, freezing, storing, etc.

In every field of agricultural production analyzed in this paper, there are planning solutions which would contribute to development of that production in some future period of time.

In crop production:

- Preservation and improvement of agricultural land production potentials,

- Food safety of agricultural products' consumers,

- High-quality raw materials for food industry, as domestic, as well as of foreign companies interested for our market,

- Production of crop and vegetable seeds for domestic producers and for export,

- Production of characteristic products meant for export.

In vegetable production:

- Increasing areas under vegetables,

- Introducing growing of vegetables as a second crop,

- Increasing areas for growing indoor vegetables - in plastic-foil houses and glasshouses,

- $\quad$ To modernize production by introduction of new varieties with higher yields and using modern mechanization,

- To provide conditions for storing and sale of final products (packing, packaging, transport, distributive centres, long-term and short-term storing, marketing, etc.).

In production of forage crops:

- Increasing of total areas under cultivated forage crops,

- Increase of share of areas under perennial legumes (lucerne, bird's-foot trefoil), field pea, vetch, broad bean, etc,

- Improvement of preparing, preservation and storing animal food,

A great and special influence to long-term stabilization of agricultural production and its intensification as a whole have those activities linked to the field of irrigation and drainage (Kljajić, et al., 2013a). 
Irrigation has technical, technological, social, economic and ecological character. In our conditions there is growing need for increased application of this measure and also for higher level of use of already existing, in other words already constructed irrigation systems.

In planning the production in conditions when there is irrigation used, it is necessary to study in detail economic advantage and shortages and ecological consequences. Advantages of irrigation are the following:

-more rational use of natural resources, first of all the use of soil;

-reduced or eliminated risk from droughts;

-relation soil-water-plant in accordance at higher rate;

-higher income per capacity unit;

-production is economically more efficient (Kljajić, et al., 2013b).

Modern agricultural production requires also modernization of agricultural mechanization (Spatial Planning of the municipality Pecinci).

\section{Conclusion}

Agriculture is one of the basic components of the development of Serbia, because, besides economic it has remarkable social and ecological importance. There are many challenges of competitiveness increase for agriculture. Therefore it is neccessary to accelerate and adjust processes of restructuring in agriculture by support of government. Also, agriculture of Serbia needs to increase its own competitiveness on international market in short time period (Cecić, et al., 2006).

For successful development of agricultural production, there is necessary the rational strategic planning and financing of agriculture by the state. A state should make the preconditions for the development of agro-credits market (http://www.makroekonomija. org/poljoprivreda/stanje-i-potencijali-u-proizvodnji-hrane-u-srbiji-2013/).

As the strategic developmental priority on the area of the municipality Pecinci, it considers activating all its natural, created and working potentials.

The basic production potential is agricultural land on which is possible to realize diverse agricultural production and its valorisations through increase of level of the basic products finalization, supplement of the production program for needs of food industry and introduction of new technologies.

Since regular use of fertilizers in the intensive agricultural production should base on knowing all previously mentioned factors of land fertility (we must turn to), there is necessary that the systematic control of land fertility in the future time implements and comprehends as an obligatory, strategic measure. This is inevitable, not only due to the rational use of adequate amounts and types of fertilizers, yield increase and plants quality, but also as a base for the control and elimination of undesirable ecological factors (through elimination of polluters, pronounced acidity and alkalinity of soil) in agricultural areas of our country (http://www.agrotim.rs/poljoprivreda/kontrola-plodnosti-zemljistau-funkciji-unapredenja-biljne-proizvodnje-i-zastite)

In regard to it, it is necessary to apply the following measures and activities: strengthening of agriculture competitiveness; improvement of agricultural production and sale (with emphasis on production specialization); creation of agro-food clusters; strengthening of food industry; diversification of rural economy (tourism, handicraft trades, recreation); arrangement of rural settlements; modernization and rationalization of system of knowledge and information exchange in agriculture; preservation and 
improvement of the natural environment and providing the sustainable utilization of natural resources; program of products geographic origin protection etc. (Spatial Planning of the municipality Pecinci).

During the process of more intensive focus on the market economy, changes in sector, being a factor of socio-economic progress, point at the necessity of expansion of activities that will lead towards growth in competition. In accordance, economic agrarian development should be a component of a strategy, which forecasts not only the aims of mid-term period development, but possible scenarios as well, based on which those aims could be realized (Kljajić, et al., 2009b.).

\section{References}

Cecić N., Jeločnik M., \& Arsić S. (2006). Stimulating measures for improvement of rural areas of Serbia. Conferinţa internaţională ,Dezvoltarea complexă a spaţiului rural”, Volumul I, Diversificarea activităţilor economice din mediul rural şi creşterea competitivităţii agriculturii, Bucureşti, 23-24 iunie 2006. Academia de Studii Economice din Bucureşti, Facultatea de Economie Agroalimentară şi a Mediului, Institutul de Economie Agrară din Belgrad, Institutul de Economie Agrară din Bucureăti, 312-321.

Cvijanović, D., Branko, K., \& Nataša, K. (2009). Rural development in Serbiaregional dissimilarities and problems. The economic and social conditions of the development of the Polish food economy following Poland's accession to the European Union-Multi-Annual Programme 2005, (128.1), 107-120.

Grujić, B., Kljajić, N., \& Roljević, S. (2014). Impact of globalization on vegetable crops production per capita in Serbia (2000-2012). Ekonomika, 60(4), 241-251.

Kljajić N., Subić J., \& Vuković P. (2009a). Proizvodnja povrća u plastenicima uz primenu navodnjavanja. Zbornik naučnih radova sa XXIII savetovanja agronoma, veterinara i tehnologa, 15( 1-2), 135-146.

Kljajić N., Subić J., \& Arsić, S. (2009b). Agricultural Land use Scenario for Pančevo City Area. In Procedings, XIII International Eco-Conference-Environmental Protection of Urban and Suburban Settlements, 23rd-26th September, 123-130.

Kljajić N., Arsić S., Vuković P. (2011). Land use in agriculture of the Republic of Serbia, The international symposium: "Agrarian economy and rural development - realites and perspectives for Romania”. September $8^{\text {th }} 9^{\text {th }}$ 2011., Bucharest, Romania.

Kljajić, N., Vuković, P., \& Arsić, S. (2013). Current situation in irrigation in the Republic of Serbia. Sustainable Technologies, Policies, and Constraints in the Green Economy, 123-139.

Kljajić N., Grujić B., \& Vuković P, (2013). Analiza proizvodnje povrća u Republici Srbiji, Zbornik naučnih radova sa XXVII savetovanja agronoma, veterinara, tehnologa i agroekonomista, 19(1-2), 261-272.

Kljajić N., Vuković P., (2014) Fruit Production Analysis in Republic of Serbia in the Function of Rural Development. In International Scientific Conference. Sustainable Agriculture and Rural Development in Terms of the Republic of Serbia Strategic Goals Realization within the Danube Region, Rural development and (un) limited resources, Belgrade, Serbia, 5-6 June, 2014. (pp. 444-460). Institute of Agricultural Economics. 
Subić J., Cecić N., \& Vuković P. (2008). Economic Aspects of Vegetable Growers' Association in Pančevo Municipality. Buletinul, 60(5A). Special Issue with Papers Presented at the International Conference: "Science and Tehnology in the Context of Sustainable Development", Organiyed on the Occasion of the $60^{\text {th }}$ Anniversary of Petroleum-Gas University of Ploiesti. Ploiesti, November 6-7, 2008, pp. 23-28.

Republički zavod za statistiku, http://webrzs.stat.gov.rs/WebSite/Statistički godišnjaci iz perioda 2000-2014.(25.03.2015).

Spatial Planning of the municipality Pecinci, 2014. (http://pecinci.org/upload/ documents/Urbanizam/PPOP/PPO\%20Pecinci.pdf) (26.08.2015)

http://www.makroekonomija.org/poljoprivreda/stanje-i-potencijali-u-proizvodnjihrane-u-srbiji-2013/(03.09.2015.)

http://www.agrotim.rs/poljoprivreda/kontrola-plodnosti-zemljista-u-funkcijiunapredenja-biljne-proizvodnje-i-zastite (03.09.2015.)

http://www.pecinci.org/opstina_pecinci/o_nama.1.html (23.08.2015.) 
